\title{
Sistem Pendukung Keputusan Pemilihan Sekolah Dasar Islam di Pontianak
}

\section{Decision Support System Selection Islamic Primary Schools in Pontianak}

\author{
Ana Fitriana*1, Tri Widayanti ${ }^{2}$ \\ 1,2Sistem Informasi STMIK Pontianak \\ E-mail: *1afitriana186@gmail.com, ${ }^{2}$ triwidayanti69@gmail.com
}

\begin{abstract}
Abstrak
Penggunaan Sistem pendukung keputusan pada pemilihan sekolah dasar Islam di Pontianak adalah untuk membantu orang tua yang akan menyekolahkan anaknya di sekolah dasar Islam Pontianak yang tepat sesuai dengan harapan orang tua. Keputusan ini tentunya didukung oleh beberapa kriteria antara lain adalah akreditasi, program pembelajaran, kualitas guru, fasilitas sekolah, lingkungan sekolah dan output dan prestasi. Kriteria-kriteria tersebut diperoleh berdasarkan kuesioner dan wawancara dengan wali murid sekolah dasar islam. Sistem pendukung keputusan pemilihan sekolah dasar Islam Pontianak menggunakan metode Analytical Hierarchy Process (AHP), dimana proses pengambilan keputusan dilakukan dengan menilai alternatif pilihan berdasarkan kriteria yang sudah di tentukan. Hasil perhitungan memperlihatkan bahwa kriteria yang terpenting di dalam pemilihan sekolah dasar islam adalah output dan prestasi yang dihasilkan dengan nilai 0,488, diikuti dengan kriteria akreditasi dengan nilai 0,359, kriteria proses pembelajaran dengan nilai 0,253, kriteria kualitas guru dengan nilai 0,158, kriteria fasilitas sekolah dengan nilai 0,150, dan lingkungan sekolah dengan nilai 0,069.
\end{abstract}

Kata Kunci — Sistem Penunjang Keputusan, Analytical Hierarchy Process, Sekolah Dasar Islam

The purpose of decision support system selection the Islamic elemantry school is to help parents who are sending their kids to Islamic elementary school in Pontianak appropriate to their expectations. The decisions supported by several criterias there are accreditation, learning program, teacher quality, school facilitation, school environment, and achievement and output. Those criteria shown by results of parent's answer who send their kids school at Islamic Elementary school at Pontianak via quessionnaire and interview Decision support system to choose Islamic elementary school in Pontianak using analytical hierarchy process (AHP) method, in which decision processing performed with assessing the alternative option based on several criteria that shown by its parents who send their kids to Islamic Elementary School in Pontianak from interview and questionnaire results. The result indicate achievement and output is the most important criteria is at 0,488, and then 0,359 acreditation, 0,253 learning program, 0,158 teacher quality, 0,150 school facility, and last is school environtment 0,069.

Keywords - Decision Support System, Analytical Hierarchy Process, Islamic Elementary School 


\section{PENDAHULUAN}

Saat ini pilihan sekolah yang ada sangat beragam, mulai dari sekolah negeri berkualitas, sekolah berbasis agama, sekolah bertaraf internasional, atau sekolah berpola khusus semacam sekolah alam, sehingga semakin mempersulit para orang tua untuk menentukan pilihan sekolah yang terbaik bagi putra putri mereka. Sekolah yang baik dan sesuai tidak hanya menentukan masa depannya kelak, tetapi memiliki sumbangsih besar dalam membentuk karakter pribadi dan perilakunya. Terlebih dalam pemilihan sekolah formal dasar baik sekolah umum maupun yang berkonsep agama.

Jumlah Sekolah Dasar yang menawarkan konsep Sekolah Dasar Islam di Pontianak ada 37 sekolah dasar Islam yang tersebar di seluruh kecamatan yang ada di Pontianak [1]. Dari ke 37 sekolah tersebut belum diketahui secara detail kualifikasi masing-masing sekolah, sehingga menyulitkan bagi para orang tua untuk menentukan sekolah mana yang tepat bagi putra putri mereka.

Adapun kualifikasi yang perlu diperhatikan oleh orang tua dalam memilih sekolah dasar Islam berdasarkan hasil wawancara dan penyebaran kuesioner kepada orang tua siswa sekolah dasar Islam yang ideal ada lima kriteria yaitu akreditasi, proses pembelajaran, kualitas guru, fasilitas sekolah, lingkungan sekolah, dan output dan prestasi yang dihasilkan. Hal-hal tersebut perlu dipertimbangkan karena memilih Sekolah Dasar Islam yang tepat merupakan tantangan bagi setiap orang tua dalam upaya mencetak generasi yang berhasil secara akademis dan religis. Hanya saja pilihan ini tidaklah mudah. Beragam hambatan ini semakin mempersulit pemilihan keputusan orang tua dalam menentukan sekolah dasar Islam terbaik bagi anak dan tidak salah pilih. Karena mengingat rutinitas belajar dan interaksi anak di sekolah tersebut akan berlangsung dalam waktu yang tidak singkat.

Menyadari betapa pentingnya dalam menentukan pilihan sekolah yang tepat, maka perlu dibuatkan sistem pendukung keputusan (SPK) yang dapat membantu para orang tua yang baru pertama kali menyekolahkan anak sehingga bisa dipastikan informasi dan pengalaman terbatas, sehingga dengan adanya sistem pendukung keputusan ini dapat membantu para orang tua dalam menentukan pilihan sekolah dasar islam terbaik bagi putra putri mereka. Sistem penunjang keputusan merupakan pendekatan sistematis, yang diawali dengan permasalahan pembuatan keputusan manajemen, pengumpulan fakta-fakta, menetapkan sejumlah kriteria keputusan untuk memilih alternatif-alternatif tindakan yang paling tepat sebagai solusi keputusan. Sistem penunjang keputusan merupakan sistem informasi interaktif yang menyediakan informasi, pemodelan, dan memanipulasi data yang digunakan untuk membantu pengambilan keputusan dalam situasi yang semiterstruktur dan tidak terstruktur [2].

Penelitian yang terkait dengan sistem pengambilan keputusan pemilihan sekolah dasar Islam di Pontianak menggunakan metode AHP yang relevan diantaranya sistem pendukung keputusan dengan menggunakan metode Multi-Criteria Decision Making (MCDM) dan AHP dapat digunakan membantu para lulusan Sekolah Menengah Kejuruan Teknik Komputer dan Jaringan (SMK TKJ) yang terfavorit dari beberapa pilihan sekolah yang ada [3]. Adapun tujuan penelitian ini adalah menghasilkan sebuah Sistem Pendukung Keputusan (SPK) untuk mempermudah pengambilan keputusan penentuan melanjutkan ke sebuah Sekolah Menengah Kejuruan (SMK) berprogram studi Teknologi Informasi (TI) yang favorit. Sehingga hal ini dapat membantu para siswa-siswi lulusan SMP atau MTs tersebut umumnya dan khususnya bagi guru, dan orang tua siswa di sekolah tersebut dalam menentukan sekolah yang tepat untuk yang sesuai dengan minat serta kemampuan yang dimiliki. Menentukan pilihan sekolah yang tepat merupakan permasalahan yang sulit bagi siswa dan orangtuanya karena terdapat banyak pilihan sekolah yang dapat membingungkan dan mengalami kesulitan untuk mendapatkan data dan informasi secara lengkap. Terdapat juga penelitian sebelumnya dengan permasalahan yang hampir sama yaitu Model Sistem Pendukung Keputusan Pemilihan Sekolah dengan menggunakan kriteria cost dan kriteria benefit. Kriteria cost meliputi: biaya perbulan, biaya uang gedung, rerata nilai ujian akhir nasional dan jarak dari rumah ke sekolah sedangkan kriteria benefit yaitu status akreditasi sekolah, ketersediaan ekstrakurikuler, dan ketersediaan fasilitas sekolah. Penelitian tersebut menggunakan 
metode SAW yaitu metode penjumlahan terbobot. Konsep dasar metode SAW adalah mencari penjumlah terbobot dari rating kinerja pada setiap alternatif dari semua kriteria. Metode ini memerlukan langkah perhitungan normalisasi matriks keputusan (X) ke suatu skala yang dapat dibandingkan dengan semua rating alternatif yang ada. Metode SAW mengenal dua jenis kriteria, yaitu cost dan benefit. Cost merupakan jenis kriteria yang mengutamakan nilai terendah, sedangkan benefit merupakan jenis kriteria yang mengutamakan nilai tertinggi sebagai acuan pemilihan [4].

Peneliti pendukung lainya adalah sistem pendukung keputusan seleksi sumber daya manusia dengan metode Technique for Order Preference by Similarity to Ideal Solution (TOPSIS). Metode TOPSIS merupakan metode yang dapat digunakan untuk menyelesaikan masalah yang multi kriteria berdasarkan konsep dimana alternatif terpilih yang terbaik tidak hanya memiliki jarang terpendek dari solusi ideal positif, namun juga memiliki jarak terpanjang dari ideal negative [5].

Merujuk kepada penelitian sebelumya, penelitian ini menggunakan metode AHP (Analytical Hierarchy Proces) dalam menentukan model dan simulasi pemilihan sekolah dasar Islam di Pontianak. Keunggulan metode AHP terhadap metode yang lain adalah struktur yang berhirarki, sebagai konsekuensi dari kriteria yang dipilih, sampai pada subkriteria yang paling dalam dan memperhitungkan validitas sampai dengan batas toleransi inkonsistensi berbagai kriteria dan alternatif yang dipilih oleh para pengambil keputusan [6]. Metode ini dipilih karena sesuai dengan tujuan penelitian ini untuk mencari prioritas dari kriteria yang ada dalam memilih sekolah dasar Islam di Pontianak. Kriteria yang digunakan dalam penelitian ini diperoleh dari hasil wawancara dan kuesioner dengan para orang tua yang menyekolahkan anaknya di sekolah dasar Islam.

\section{METODE PENELITIAN}

Penelitian ini dilakukan dengan menggunakan metode Analytical Hierarchy Proces (AHP). AHP memiliki banyak keunggulan dalam menjelaskan proses pengambilan keputusan. Salah satunya adalah dapat digambarkan secara grafis sehingga mudah dipahami oleh semua pihak yang terlibat dalam pengambilan keputusan. Dalam menyelesaikan permasalahan dengan AHP ada beberapa prinsip yang harus dipahami, diantaranya adalah membuat hierarki, yaitu menguraikan sistem yang kompleks bisa dipahami dengan memecahnya menjadi elemen-elemen pendukung, menyusun elemen secara hierarki, dan menggabungkannya atau mensintensisnya. Tahapan selanjutnya adalah membuat penilaian kriteria dan alternatif yang dilakukan dengan perbandingan berpasangan. Untuk berbagai persoalan, skala 1 sampai 9 adalah skala terbaik untuk mengekspresikan pendapat. Nilai dan definisi pendapat kualitatif dari skala perbandingan Saaty bisa diukur menggunakan tabel analisis seperti ditunjukkan pada tabel 1 berikut [7]:

Tabel 1. Skala Penilaian Perbandingan Pasangan

\begin{tabular}{|c|l|}
\hline $\begin{array}{c}\text { Intensitas } \\
\text { Kepentingan }\end{array}$ & \multicolumn{1}{c|}{ Keterangan } \\
\hline 1 & Kedua elemen sama penting \\
\hline 3 & Elemen yang satu sedikit lebih penting dari pada elemen lainnya \\
\hline 5 & Elemen yang satu lebih penting dari pada elemen lainnya \\
\hline 7 & Satu elemen jelas lebih mutlak penting dari pada elemen lainnya \\
\hline 9 & Satu elemen mutlak penting dari pada elemen lainnya \\
\hline 2468 & Nilai - nilai antara dua nilai pertimbangan yang berdekatan \\
\hline Kebalikan & $\begin{array}{l}\text { Jika aktivitas i mendapat satu angka dibandingkan dengan aktivitas } \mathrm{j}, \\
\text { maka i memiliki nilai kebalikannya dibandingkan dengan i }\end{array}$ \\
\hline
\end{tabular}


Setelah tahapan perbandingan kriteria dan alternatif maka langkah selanjutnya menentukan synthesis of Priority, dimana untuk setiap kriteria dan alternatif, perlu dilakukan perbandingan berpasangan (pairwise Comparisons). Nilai-nilai perbandingan relatif dari seluruh alternatif kriteria bisa disesuaikan dengan judgement yang telah ditentukan untuk menghasilkan bobot dan prioritas. Bobot dan prioritas dihitung dengan memanipulasi matriks atau melalui penyelesain persamaan matematika. Hasil perhitungan di atas akan menghasilkan Logical Consistency. Untuk mengetahui seberapa baik konsistensi yang ada karena kita tidak menginginkan keputusan berdasarkan pertimbangan dengan konsistensi yang rendah. Konsistensi memiliki dua makna. Pertama, objek-objek yang serupa bisa dikelompokkan sesuai dengan keseragaman dan relevansi. Kedua, menyangkut tingkat hubungan antar objek yang didasarkan pada kriteria tertentu. Dengan menggunakan rumus hitung Consistency Index (CI) dengan rumus $\mathrm{CI}=(\lambda$ maksn $) / \mathrm{n}$. Dimana $\mathrm{n}=$ banyaknya elemen. Kemudian menghitung Consistency Ratio(CR) dengan rumus: $\mathrm{CR}=\mathrm{CI} / \mathrm{RC}$. Sedangkan RC adalah Random Cosistency dengan skala penilaian 1 sampai 9 beserta kebalikannya dapat dilihat pada tabel 2. Memeriksa konsistensi hierarki. Jika nilainya lebih dari 10\%, maka penilain data judgment harus diperbaiki. Namun jika rasio konsistensi (CI/CR) kurang atau sama dengan 0,1, maka hasil perhitungan bisa dinyatakan benar.

Tabel 2. Nilai Rata-Rata Konsistensi

\begin{tabular}{|c|c|}
\hline Ukuran Matriks & Random Consistency \\
\hline 1 dan 2 & 0,00 \\
\hline 3 & 0,58 \\
\hline 4 & 0,90 \\
\hline 5 & 1,12 \\
\hline 6 & 1,24 \\
\hline 7 & 1,32 \\
\hline 8 & 1,41 \\
\hline 9 & 1,45 \\
\hline 10 & 1,49 \\
\hline
\end{tabular}

\section{HASIL DAN PEMBAHASAN}

SPK pemilihan sekolah dasar yang ada di Pontianak dilakukan melalui tahapan-tahapan dalam metode AHP dimana metode AHP terdiri dari decomposition, comparative judgement, synthesis of priority, dan logical consistency. Sebelum melakukan perhitungan dengan metode AHP, SPK pemilihan sekolah dasar dimulai dengan melakukan analisa data dimana analisa data dilakukan untuk menentukan data yang digunakan dalam menentukan sekolah dasar yang terbaik untuk dipilih oleh para orang tua. Data dikumpulkan dari kuesioner dan teknik wawancara kepada beberapa para orang tua murid sekolah dasar yang menyekolahkan anaknya di sekolah dasar untuk mengetahui apa saja yang yang menjadi kriteria dalam memilih sekolah dasar yang tepat bagi anak mereka. Hasil kuesioner dan wawancara tersebut menghasilkan 6 (enam) kriteria yang paling banyak digunakan oleh orang tua dalam memilih sekolah dasar antara lain adalah akreditasi, proses pembelajaran, kualitas guru, fasilitas sekolah, lingkungan sekolah, dan output dan prestasi yang dihasilkan.

Banyak orang tua murid menyatakan bahwa kriteria akreditasi sebagai panduan mereka untuk menilai kualitas sekolah dasar Islam. Dengan akreditasi mereka menganggap bahwa sekolah memiliki kualitas yang sesuai harapan yang mereka inginkan. Kemudian kriteria proses pembelajaran menjadi pertimbangan berikutnya karena dapat mengetahui proses belajar yang terjadi disekolah tersebut efektif atau tidaknya dalam menyampaikan pelajaran guna mudah dimengerti oleh peserta didik. Untuk kriteria kualitas guru juga mempengaruhi didalam pemilihan sekolah dasar yang baik. Guru menjadi objek penting didalam keberhasilan proses pendidikan. Dimana dengan guru yang memiliki kesabaran, ketelatenan, dan pintar menemukan metode ajar 
yang tepat bagi peserta didik agar mudah dipahami. Selain itu, kriteria fasilitas sekolah juga mendukung keberhasilan didalam proses pendidikan, fasilitas sekolah yang lengkap sangat diinginkan oleh orang tua. Kriteria lingkungan sekolah juga dinyatakan sebagai pertimbangan didalam menyekolahka putra putri mereka karena lingkungan yang nyaman dan aman akan mendukung proses pembelajaran yang efektif. Kriteria yang juga diinginkan oleh orang tua yaitu output dan prestasi yang dihasilkan di sekolah tersebut.

Alternatif yang dijadikan pilihan sekolah dasar dalam penelitian ini adalah empat sekolah dasar Islam yang ada di Pontianak yaitu SD Muhammadiyah 2, SDIT Al-Mumtaz, SDI Mujahidin, dan SDI Al-Azhar. Setelah menentukan data kriteria dan alternatif maka tahapan AHP dapat dimulai dari penyusunan hirarki yaitu dengan menentukan tujuan yang merupakan sasaran sistem secara keseluruhan di tingkat teratas. Tingkatan selanjutnya terdiri dari kriteria-kriteria untuk menilai alternatif-alternatif yang ada dan menentukan nilai alternatif-alternatif tersebut. Hubungan antara kriteria dan alternatif dalam SPK pemilihan sekolah Islam dapat dilihat pada Gambar 1.

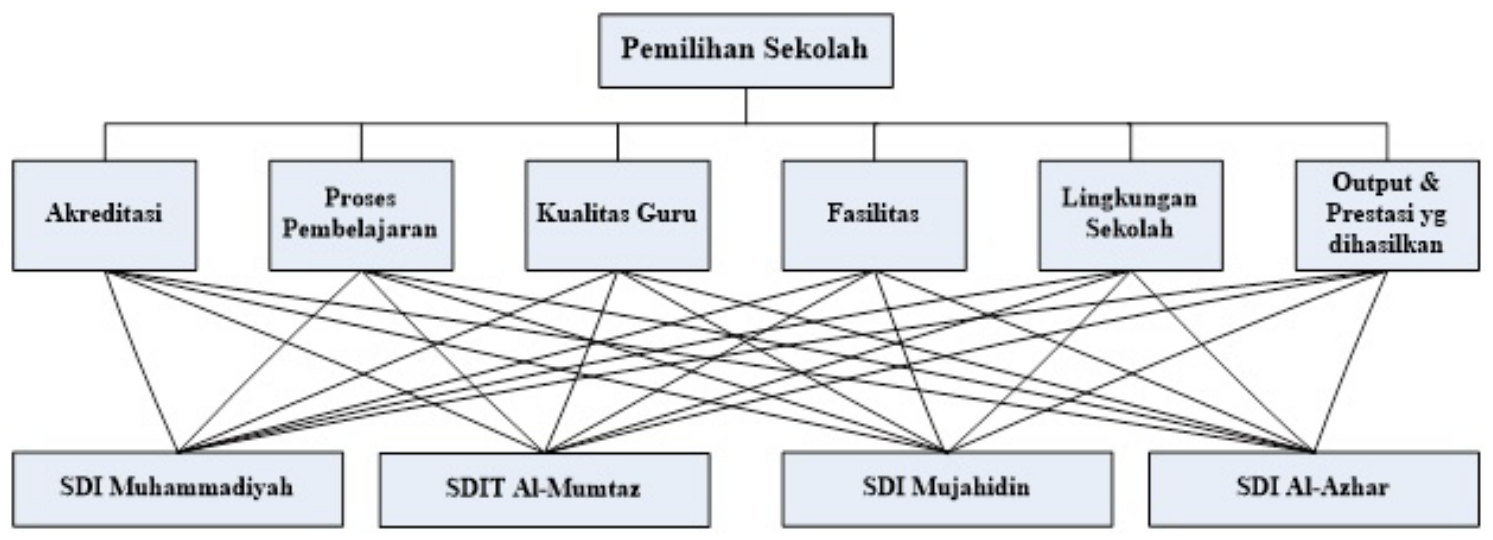

Gambar 1. Hubungan antara Kriteria dan Alternatif dalam AHP

Tahapan AHP selanjutnya adalah pair-wise comparation yaitu membandingkan kriteria satu sama lain kemudian diisi nilai bobotnya berdasarkan tingkat kepentingan dari kriteria tersebut. Nilai perbandingan kriteria didapat dari kuesioner yang disebar kepada 50 responden yang sudah pernah menyekolahkan putra putrinya di sekolah dasar Islam, untuk melihat kriteria yang paling penting dari keenam kriteria tersebut. Hasil perbandingan tingkat kepentingan kriteria pemilihan sekolah dasar Islam dapat dilihat pada Tabel 3 berikut ini.

Tabel 3. Matrik Perbandingan Berpasangan Kriteria

\begin{tabular}{|c|c|c|c|c|c|c|}
\hline Kriteria & AKR & PP & KG & FS & LS & O\&P \\
\hline AKR & 1.000 & 2.000 & 3.000 & 3.000 & 4.000 & 0.500 \\
\hline PP & 0.500 & 1.000 & 4.000 & 2.000 & 3.000 & 0.333 \\
\hline KG & 0.333 & 0.250 & 1.000 & 2.000 & 3.000 & 0.500 \\
\hline FS & 0.333 & 0.500 & 0.500 & 1.000 & 5.000 & 0.333 \\
\hline LS & 0.250 & 0.333 & 0.333 & 0.200 & 1.000 & 0.250 \\
\hline O\&P & 2.000 & 3.000 & 2.000 & 3.000 & 4.000 & 1.000 \\
\hline Jumlah & 2.167 & 3.750 & 8.500 & 8.000 & 16.000 & 2.917 \\
\hline
\end{tabular}

Selain perbandingan kriteria di atas, matriks pair-wise comparation juga dibuat untuk membandingkan alternatif dengan masing-masing kriteria yang telah ditetapkan. Dalam penelitian ini terdapat empat sekolah dasar Islam yang dijadikan sampel yaitu SDI Muhammadiyah 2, SDIT Al Mumtaz, SDI Mujahidin, SDI Al Azhar. Adapun hasil perbandingan aternatif untuk setiap kriteria dapat dilihat pada Tabel 4 sampai dengan Tabel 9. 
Tabel 4. Matrik Perbandingan Alternatif Akreditasi

\begin{tabular}{|l|c|c|c|c|}
\hline \multicolumn{1}{|c|}{ Alternatif } & $\begin{array}{c}\text { SDI } \\
\text { Muhammadiyah }\end{array}$ & $\begin{array}{c}\text { SDIT } \\
\text { Al-Mumtaz }\end{array}$ & $\begin{array}{c}\text { SDI } \\
\text { Mujahidin }\end{array}$ & $\begin{array}{c}\text { SDI } \\
\text { Al-Azhar }\end{array}$ \\
\hline SDI Muhammadiyah & 1.00 & 0.50 & 2.00 & 2.00 \\
\hline SDIT Al-Mumtaz & 2.00 & 1.00 & 2.00 & 2.00 \\
\hline SDI Mujahidin & 0.50 & 0.50 & 1.00 & 0.50 \\
\hline SDI Al-Azhar & 0.50 & 0.50 & 2.00 & 1.00 \\
\hline \multicolumn{1}{|c|}{ Jumlah } & 4.00 & 2.50 & 7.00 & 5.50 \\
\hline
\end{tabular}

Tabel 5. Matrik Perbandingan Alternatif Proses Pembelajaran

\begin{tabular}{|l|c|c|c|c|}
\hline \multicolumn{1}{|c|}{ Alternatif } & $\begin{array}{c}\text { SDI } \\
\text { Muhammadiyah }\end{array}$ & $\begin{array}{c}\text { SDIT } \\
\text { Al-Mumtaz }\end{array}$ & $\begin{array}{c}\text { SDI } \\
\text { Mujahidin }\end{array}$ & $\begin{array}{c}\text { SDI } \\
\text { Al-Azhar }\end{array}$ \\
\hline SDI Muhammadiyah & 1.00 & 0.50 & 2.00 & 2.00 \\
\hline SDIT Al-Mumtaz & 2.00 & 1.00 & 3.00 & 2.00 \\
\hline SDI Mujahidin & 0.50 & 0.33 & 1.00 & 0.33 \\
\hline SDI Al-Azhar & 0.50 & 0.50 & 3.00 & 1.00 \\
\hline \multicolumn{1}{|c|}{ Jumlah } & 4.00 & 2.33 & 9.00 & 5.33 \\
\hline
\end{tabular}

Tabel 6. Matrik Perbandingan Alternatif Kualitas Guru

\begin{tabular}{|l|c|c|c|c|}
\hline \multicolumn{1}{|c|}{ Alternatif } & $\begin{array}{c}\text { SDI } \\
\text { Muhammadiyah }\end{array}$ & $\begin{array}{c}\text { SDIT } \\
\text { Al-Mumtaz }\end{array}$ & $\begin{array}{c}\text { SDI } \\
\text { Mujahidin }\end{array}$ & $\begin{array}{c}\text { SDI } \\
\text { Al-Azhar }\end{array}$ \\
\hline SDI Muhammadiyah & 1.00 & 0.33 & 2.00 & 3.00 \\
\hline SDIT Al-Mumtaz & 3.00 & 1.00 & 5.00 & 3.00 \\
\hline SDI Mujahidin & 0.50 & 0.20 & 1.00 & 0.50 \\
\hline SDI Al-Azhar & 0.33 & 0.33 & 2.00 & 1.00 \\
\hline \multicolumn{1}{|c|}{ Jumlah } & 4.83 & 1.87 & 10.00 & 7.50 \\
\hline
\end{tabular}

Tabel 7. Matrik Perbandingan Alternatif Fasilitas Sekolah

\begin{tabular}{|l|c|c|c|c|}
\hline \multicolumn{1}{|c|}{ Alternatif } & $\begin{array}{c}\text { SDI } \\
\text { Muhammadiyah }\end{array}$ & $\begin{array}{c}\text { SDIT } \\
\text { Al-Mumtaz }\end{array}$ & $\begin{array}{c}\text { SDI } \\
\text { Mujahidin }\end{array}$ & $\begin{array}{c}\text { SDI } \\
\text { Al-Azhar }\end{array}$ \\
\hline SDI Muhammadiyah & 1.00 & 2.00 & 2.00 & 0.50 \\
\hline SDIT Al-Mumtaz & 0.50 & 1.00 & 2.00 & 0.33 \\
\hline SDI Mujahidin & 0.50 & 0.50 & 1.00 & 0.25 \\
\hline SDI Al-Azhar & 2.00 & 3.00 & 4.00 & 1.00 \\
\hline \multicolumn{1}{|c|}{ Jumlah } & 4.00 & 6.50 & 9.00 & 2.08 \\
\hline
\end{tabular}

Tabel 8. Matrik Perbandingan Alternatif Lingkungan Sekolah

\begin{tabular}{|l|c|c|c|c|}
\hline \multicolumn{1}{|c|}{ Alternatif } & $\begin{array}{c}\text { SDI } \\
\text { Muhammadiyah }\end{array}$ & $\begin{array}{c}\text { SDIT } \\
\text { Al-Mumtaz }\end{array}$ & $\begin{array}{c}\text { SDI } \\
\text { Mujahidin }\end{array}$ & $\begin{array}{c}\text { SDI } \\
\text { Al-Azhar }\end{array}$ \\
\hline SDI Muhammadiyah & 1.00 & 2.00 & 2.00 & 0.33 \\
\hline SDIT Al-Mumtaz & 0.50 & 1.00 & 2.00 & 0.33 \\
\hline SDI Mujahidin & 0.50 & 0.50 & 1.00 & 0.25 \\
\hline SDI Al-Azhar & 3.00 & 3.00 & 4.00 & 1.00 \\
\hline \multicolumn{1}{|c|}{ Jumlah } & 5.00 & 6.50 & 9.00 & 1.92 \\
\hline
\end{tabular}


Citec Journal, Vol. 4, No. 1, November 2016 - Januari 2017

ISSN: 2460-4259

Tabel 9. Matrik Perbandingan Alternatif Output dan Prestasi yang Dihasilkan

\begin{tabular}{|l|c|c|c|c|}
\hline \multicolumn{1}{|c|}{ Alternatif } & $\begin{array}{c}\text { SDI } \\
\text { Muhammadiyah }\end{array}$ & $\begin{array}{c}\text { SDIT } \\
\text { Al-Mumtaz }\end{array}$ & $\begin{array}{c}\text { SDI } \\
\text { Mujahidin }\end{array}$ & $\begin{array}{c}\text { SDI } \\
\text { Al-Azhar }\end{array}$ \\
\hline SDI Muhammadiyah & 1.00 & 2.00 & 2.00 & 2.00 \\
\hline SDIT Al-Mumtaz & 0.50 & 1.00 & 3.00 & 2.00 \\
\hline SDI Mujahidin & 0.50 & 0.33 & 1.00 & 0.33 \\
\hline SDI Al-Azhar & 0.50 & 0.50 & 3.00 & 1.00 \\
\hline \multicolumn{1}{|c|}{ Jumlah } & 2.50 & 3.83 & 9.00 & 5.33 \\
\hline
\end{tabular}

Tahap selanjutnya setelah proses pair-wise comparation selesai dilakukan adalah melakukan normalisasi matriks untuk mencari EigenValue terhadap kriteria seperti ditampilkan pada Tabel 10. Sedangkan normalisasi matrik untuk kriteria akreditasi (AKR), kriteria proses pembelajaran (PP), kriteria kualitas guru (KG), kriteria fasilitas sekolah (FS), kriteria lingkungan sekolah (LS), dan kriteria output dan prestasi yang dihasilkan (O\&P) dapat dilihat pada Tabel 11. Adapun cara untuk memperoleh tabel normalisasi matriks dilakukan dengan membagi nilai dari setiap elemen di dalam matriks yang berpasangan dengan nilai total dari setiap kolom.

Tabel 10. Normalisasi Matrik Kriteria

\begin{tabular}{|c|c|c|c|c|c|c|c|}
\hline KRITERIA & AKR & PP & KG & FS & LS & O\&P & EIGEN VALUE \\
\hline AKR & 0.462 & 0.533 & 0.353 & 0.375 & 0.250 & 0.171 & 0.357 \\
\hline PP & 0.231 & 0.267 & 0.471 & 0.250 & 0.188 & 0.114 & 0.253 \\
\hline KG & 0.154 & 0.067 & 0.118 & 0.250 & 0.188 & 0.171 & 0.158 \\
\hline FS & 0.154 & 0.133 & 0.059 & 0.125 & 0.313 & 0.114 & 0.150 \\
\hline LS & 0.115 & 0.089 & 0.039 & 0.025 & 0.063 & 0.086 & 0.069 \\
\hline O\&P & 0.923 & 0.800 & 0.235 & 0.375 & 0.250 & 0.343 & 0.488 \\
\hline
\end{tabular}

Berdasarkan hasil penghitungan normalisasi matriks kriteria di atas akan didapatkan Eigen value yang akan digunakan sebagai nilai pada tahap penentuan total priority value. Eigen value merupakan nilai bobot setiap elemen yang didapat dari perhitungan rata-rata disetiap baris kriteria seperti yang ditampilkan pada tabel 10. Eigen Value (EV) untuk masing-masing kriteria adalah kriteria akreditasi memiliki nilai Eigen 0,357, kriteria proses pembelajaran memiliki nilai Eigen 0,253, kriteria kualitas guru memiliki nilai Eigen 0,158, kriteria fasilitas sekolah memiliki nilai Eigen 0,150, kriteria lingkungan sekolah memiliki nilai Eigen 0,069, kriteria output dan prestasi memiliki nilai Eigen 0,488. Dari hasil nilai Eigen diatas dapat disimpulkan bahwa kriteria yang paling penting dalam pemilihan sekolah dasar Islam adalah output dan prestasi diikuti oleh akreditasi, proses pembelajaran, kualitas guru, fasilitas sekolah, terakhir lingkungan sekolah.

Tabel 11. Normalisasi Matrik Alternatif Kriteria

\begin{tabular}{|l|c|c|c|c|c|c|}
\hline \multicolumn{1}{|c|}{ Alternatif } & $\begin{array}{c}\text { EV Kriteria } \\
\text { AKR }\end{array}$ & $\begin{array}{c}\text { EV } \\
\text { Kriteria } \\
\text { PP }\end{array}$ & $\begin{array}{c}\text { EV } \\
\text { Kriteria } \\
\text { KG }\end{array}$ & $\begin{array}{c}\text { EV } \\
\text { Kriteria } \\
\text { FS }\end{array}$ & $\begin{array}{c}\text { EV } \\
\text { Kriteria } \\
\text { LS }\end{array}$ & $\begin{array}{c}\text { EV Kriteria } \\
\text { O\&P }\end{array}$ \\
\hline $\begin{array}{l}\text { SDI } \\
\text { Muhammadiyah }\end{array}$ & 0.27 & 0.27 & 0.25 & 0.25 & 0.23 & 0.38 \\
\hline SDIT Al- Mumtaz & 0.39 & 0.41 & 0.51 & 0.17 & 0.16 & 0.29 \\
\hline SDI Mujahidin & 0.14 & 0.11 & 0.09 & 0.11 & 0.10 & 0.12 \\
\hline SDI Al-Azhar & 0.20 & 0.22 & 0.15 & 0.47 & 0.51 & 0.21 \\
\hline
\end{tabular}

Tahapan selanjutnya adalah synthesis of priority yaitu membangun prioritas keseluruhan untuk AHP atau disebut total priority value. Total priority value dilakukan dengan cara menampilkan matriks bobot alternatif dan kriteria dimana kolomnya diisi dengan nilai eigen dari setiap alternatif terhadap kriteria dan nilai eigen dari kriteria yang telah dihitung sebelumnya. 
Langkah selanjutnya yaitu menghitung total skor untuk sintesis of priority dari alternatif sekolah dasar Islam dengan cara mengalikan nilai eigen dari alternatif dengan nilai Eigen dari kriteria kemudian ditotalkan setiap barisnya, ditunjukkan pada tabel 12 berikut:

Tabel 12. Total Priority Value SPK Pemilihan Sekolah Dasar Islam Pontianak

\begin{tabular}{|l|c|c|c|c|c|c|c|}
\hline \multicolumn{1}{|c|}{ Alternatif / Kriteria } & AKR & PP & KG & FS & LS & O\&P & CHOICE \\
\hline SDI Muhammadiyah & 0.098 & 0.067 & 0.039 & 0.038 & 0.016 & 0.185 & 0.443 \\
\hline SDIT Al-Mumtaz & 0.138 & 0.104 & 0.081 & 0.025 & 0.011 & 0.143 & 0.502 \\
\hline SDI Mujahidin & 0.071 & 0.054 & 0.023 & 0.071 & 0.007 & 0.056 & 0.282 \\
\hline SDI Al-Azhar & 0.128 & 0.064 & 0.025 & 0.022 & 0.035 & 0.104 & 0.378 \\
\hline
\end{tabular}

Berdasarkan hasil penghitungan yang telah dilakukan dengan menggunakan metode AHP diperoleh nilai Total Priority Value untuk masing-masing Sekolah Dasar Islam yaitu SDI Muhammadiyah memiliki 0.443, SDI Al-Mumtaz memiliki 0.502, SDI Mujahidin memiliki nilai 0.282 dan SDI Al-Azhar memiliki nilai 0.378. Sehingga dari hasil penghitungan dengan metode AHP yang direkomendasikan untuk keputusan Sekolah Dasar Islam adalah SDIT Al-Mumtaz karena memiliki nilai yang paling tinggi yaitu 0.502 .

Tahap terakhir dari metode AHP adalah melakukan proses pengujian konsistensi (logical consistency). Logical consistency dilakukan untuk melihat apakah hasil perbandingan yang diisikan sesuai dan valid dalam dunia nyata. Ukuran matriks dari kriteria SPK Pemilihan Sekolah Dasar Islam adalah 6x6 sehingga nilai konsistensi rasio harus kurang dari 1.24, sedangkan untuk matriks alternatif berukuran 4x4 dengan nilai konsistensi harus kurang dari 0.90 (Tabel 2). Jika nilai konsistensi rasio lebih dari batas tersebut maka nilai perbandingan nilai bobot matriks harus dilakukan kembali. Konsistensi diukur melalui perhitungan consistency ratio (CR) dimana CR = Consistency Index (CI)/ Random Index (RI). Nilai CI diperoleh dari penghitungan ( $\lambda$ max-n)/n-1, sedangkan RI didapatkan dari nilai yang sudah ditetapkan oleh metode AHP (Tabel 2).

Tabel 13. Pengukuran Logikal Consistency Kriteria SPK Pemilihan Sekolah Islam

\begin{tabular}{|c|c|c|c|c|c|c|c|c|}
\hline Kriteria & AKR & PP & KG & FS & LS & O\&P & Total & Summary \\
\hline AKR & 0.357 & 0.507 & 0.474 & 0.449 & 0.278 & 0.244 & 2.308 & 6.458 \\
\hline PP & 0.179 & 0.253 & 0.631 & 0.299 & 0.208 & 0.163 & 1.734 & 6.844 \\
\hline KG & 0.119 & 0.063 & 0.158 & 0.299 & 0.208 & 0.244 & 1.092 & 6.917 \\
\hline FS & 0.119 & 0.127 & 0.079 & 0.150 & 0.347 & 0.163 & 0.984 & 6.577 \\
\hline LS & 0.089 & 0.084 & 0.053 & 0.030 & 0.069 & 0.122 & 0.448 & 6.446 \\
\hline \multirow[t]{3}{*}{ O\&P } & 0.715 & 0.760 & 0.316 & 0.449 & 0.278 & 0.488 & 3.005 & 6.161 \\
\hline & & & & & & & Total & 39.403 \\
\hline & & & & & & & $\lambda \operatorname{Max}$ & 6.567 \\
\hline \multicolumn{4}{|c|}{$\begin{array}{l}\text { Consistency Index }(\mathrm{CI}) \\
\mathrm{CI}=(\lambda \text { maks }-\mathrm{n}) /(\mathrm{n}-1) \\
\mathrm{CI}=(6.567-6) /(6-1) \\
\mathrm{CI}=0.1134\end{array}$} & \multicolumn{3}{|c|}{$\begin{array}{l}\text { Consistency Rasio (CR) } \\
\mathrm{CR}=\mathrm{CI} / \mathrm{IR} \\
\mathrm{CR}=0.1134 / 1.24 \\
\mathrm{CR}=0.0915 \\
\mathrm{CR}<1.24 \\
\text { Consistent }\end{array}$} & & \\
\hline
\end{tabular}

Perhitungan nilai konsistensi rasio dari kriteria yang ditampilkan Tabel 13 menunjukkan bahwa konsistensi dapat diterima karena nilai konsistensi rasio untuk kriteria adalah 0.0915. Nilai tersebut tidak melebihi 1.24 (untuk matriks dengan ukuran 6x6) sehingga hasil perbandingan yang diisi adalah valid. Begitu pula untuk pengukuran konsistensi alternatif, konsistensi rasio yang dihasilkan semuanya dinyatakan valid, karena untuk matriks ukuran 4x4 konsistensi rasio tidak boleh melebihi 0.90 (tabel $14 \mathrm{~s} / \mathrm{d} 19$ ). 
Citec Journal, Vol. 4, No. 1, November 2016 - Januari 2017

ISSN: 2460-4259

Tabel 14. Pengukuran Logikal Consistency Alternatif untuk Kriteria Akreditasi

\begin{tabular}{|c|c|c|c|c|c|c|}
\hline Alternatif & $\begin{array}{c}\text { SDI } \\
\text { Muhammadiyah }\end{array}$ & $\begin{array}{c}\text { SDIT } \\
\text { Al-Mumtaz }\end{array}$ & $\begin{array}{c}\text { SDI } \\
\text { Mujahidin }\end{array}$ & $\begin{array}{c}\text { SDI } \\
\text { Al-Azhar }\end{array}$ & Total & Summary \\
\hline $\begin{array}{l}\text { SDI } \\
\text { Muhammadiyah }\end{array}$ & 0.27 & 0.19 & 0.28 & 0.40 & 1.14 & 4.16 \\
\hline SDIT Al-Mumtaz & 0.55 & 0.39 & 0.28 & 0.40 & 1.61 & 4.16 \\
\hline SDI Mujahidin & 0.14 & 0.19 & 0.14 & 0.10 & 0.57 & 4.08 \\
\hline SDI Al-Azhar & 0.14 & 0.19 & 0.28 & 0.20 & 0.81 & 4.08 \\
\hline & & & & & Total & 16.49 \\
\hline & & & & & $\lambda \operatorname{Max}$ & 4.12 \\
\hline \multicolumn{2}{|c|}{$\begin{array}{l}\text { Consistency Index }(\mathrm{CI}) \\
\mathrm{CI}=(\lambda \text { maks }-\mathrm{n}) /(\mathrm{n}-1) \\
\mathrm{CI}=(4.12-4) /(4-1) \\
\mathrm{CI}=0.0406\end{array}$} & \multicolumn{3}{|c|}{$\begin{array}{l}\text { Consistency Rasio (CR) } \\
\mathrm{CR}=\mathrm{CI} / \mathrm{IR} \\
\mathrm{CR}=0.0406 / 0.90 \\
\mathrm{CR}=0.045 \\
\mathrm{CR}<0.90 \text { Consistent }\end{array}$} & & \\
\hline
\end{tabular}

Tabel 15. Pengukuran Logikal Consistency Alternatif untuk Kriteria Proses Pembelajaran

\begin{tabular}{|c|c|c|c|c|c|c|}
\hline Alternatif & $\begin{array}{c}\text { SDI } \\
\text { Muhammadiyah }\end{array}$ & $\begin{array}{c}\text { SDIT } \\
\text { Al-Mumtaz }\end{array}$ & $\begin{array}{c}\text { SDI } \\
\text { Mujahidin }\end{array}$ & $\begin{array}{c}\text { SDI } \\
\text { Al-Azhar }\end{array}$ & Total & Summary \\
\hline $\begin{array}{l}\text { SDI } \\
\text { Muhammadiyah }\end{array}$ & 0.27 & 0.20 & 0.22 & 0.43 & 1.12 & 4.22 \\
\hline SDIT Al-Mumtaz & 0.53 & 0.41 & 0.33 & 0.43 & 1.70 & 4.16 \\
\hline SDI Mujahidin & 0.13 & 0.14 & 0.11 & 0.07 & 0.45 & 4.09 \\
\hline SDI Al-Azhar & 0.13 & 0.20 & 0.33 & 0.22 & 0.88 & 4.11 \\
\hline \multirow{2}{*}{\multicolumn{5}{|c|}{ 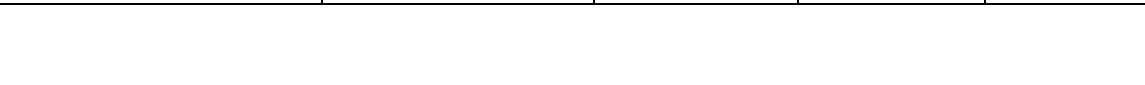 }} & Total & 16.58 \\
\hline & & & & & $\lambda \operatorname{Max}$ & 4.14 \\
\hline \multicolumn{2}{|c|}{$\begin{array}{l}\text { Consistency Index }(\mathrm{CI}) \\
\mathrm{CI}=(\lambda \text { maks }-\mathrm{n}) /(\mathrm{n}-1) \\
\mathrm{CI}=(4.14-4) /(4-1) \\
\mathrm{CI}=0.0480\end{array}$} & \multicolumn{3}{|c|}{$\begin{array}{l}\text { Consistency Rasio (CR) } \\
\mathrm{CR}=\mathrm{CI} / \mathrm{IR} \\
\mathrm{CR}=0.0480 / 0.90 \\
\mathrm{CR}=0.0534 \\
\mathrm{CR}<0.90 \text { Consistent }\end{array}$} & & \\
\hline
\end{tabular}

Tabel 16. Pengukuran Logikal Consistency Alternatif untuk Kriteria Kualitas Guru

\begin{tabular}{|c|c|c|c|c|c|c|}
\hline Alternatif & $\begin{array}{c}\text { SDI } \\
\text { Muhammadiyah }\end{array}$ & $\begin{array}{c}\text { SDIT } \\
\text { Al-Mumtaz }\end{array}$ & $\begin{array}{c}\text { SDI } \\
\text { Mujahidin }\end{array}$ & $\begin{array}{c}\text { SDI } \\
\text { Al-Azhar } \\
\end{array}$ & Total & Summary \\
\hline $\begin{array}{l}\text { SDI } \\
\text { Muhammadiyah }\end{array}$ & 0.25 & 0.17 & 0.19 & 0.44 & 1.04 & 4.23 \\
\hline SDIT Al-Mumtaz & 0.74 & 0.51 & 0.47 & 0.44 & 2.16 & 4.20 \\
\hline SDI Mujahidin & 0.12 & 0.10 & 0.09 & 0.07 & 0.39 & 4.17 \\
\hline SDI Al-Azhar & 0.08 & 0.17 & 0.19 & 0.15 & 0.59 & 4.04 \\
\hline & & & & & Total & 16.64 \\
\hline & & & & & $\lambda \operatorname{Max}$ & 4.16 \\
\hline \multicolumn{2}{|c|}{$\begin{array}{l}\text { Consistency Index }(\mathrm{CI}) \\
\mathrm{CI}=((\lambda \text { maks }-\mathrm{n}) /(\mathrm{n}-1) \\
\mathrm{CI}=((4.16-4) /(4-1) \\
\mathrm{CI}=0.0535\end{array}$} & \multicolumn{3}{|c|}{$\begin{array}{l}\text { Consistency Rasio (CR) } \\
\mathrm{CR}=\mathrm{CI} / \mathrm{IR} \\
\mathrm{CR}=0.0535 / 0.9 \\
\mathrm{CR}=0.0595 \\
\mathrm{CR}<0.90 \text { consistent }\end{array}$} & & \\
\hline
\end{tabular}


Tabel 17. Pengukuran Logikal Consistency Alternatif untuk Kriteria Fasilitas Sekolah

\begin{tabular}{|c|c|c|c|c|c|c|}
\hline Alternatif & $\begin{array}{c}\text { SDI } \\
\text { Muhammadiyah }\end{array}$ & $\begin{array}{c}\text { SDIT } \\
\text { Al-Mumtaz }\end{array}$ & $\begin{array}{c}\text { SDI } \\
\text { Mujahidin }\end{array}$ & $\begin{array}{c}\text { SDI } \\
\text { Al-Azhar }\end{array}$ & Total & Summary \\
\hline $\begin{array}{l}\text { SDI } \\
\text { Muhammadiyah }\end{array}$ & 0.25 & 0.33 & 0.22 & 0.24 & 1.04 & 4.07 \\
\hline SDIT Al-Mumtaz & 0.13 & 0.17 & 0.22 & 0.16 & 0.67 & 4.03 \\
\hline SDI Mujahidin & 0.13 & 0.08 & 0.11 & 0.12 & 0.44 & 4.03 \\
\hline SDI Al-Azhar & 0.51 & 0.50 & 0.43 & 0.47 & 1.91 & 4.05 \\
\hline & & & & Total & 16.18 \\
\hline & & & & & $\lambda \operatorname{Max}$ & 4.05 \\
\hline \multicolumn{2}{|c|}{$\begin{array}{l}\text { Consistency Index }(\mathrm{CI}) \\
\mathrm{CI}=((\lambda \text { maks }-\mathrm{n}) /(\mathrm{n}-1) \\
\mathrm{CI}=(4.05-4) /(4-1) \\
\mathrm{CI}=0.0153\end{array}$} & \multicolumn{3}{|c|}{$\begin{array}{l}\text { Consistency Rasio (CR) } \\
\mathrm{CR}=\mathrm{CI} / \mathrm{IR} \\
\mathrm{CR}=0.0153 / 0.90 \\
\mathrm{CR}=0.017 \\
\mathrm{CR}<0.90 \text { Consistent }\end{array}$} & & \\
\hline
\end{tabular}

Tabel 18. Pengukuran Logikal Consistency Alternatif untuk Kriteria Lingkungan Sekolah

\begin{tabular}{|c|c|c|c|c|c|c|}
\hline Alternatif & $\begin{array}{c}\text { SDI } \\
\text { Muhammadiyah }\end{array}$ & $\begin{array}{c}\text { SDIT } \\
\text { Al-Mumtaz }\end{array}$ & $\begin{array}{c}\text { SDI } \\
\text { Mujahidin }\end{array}$ & $\begin{array}{c}\text { SDI } \\
\text { Al-Azhar }\end{array}$ & Total & Summary \\
\hline $\begin{array}{l}\text { SDI } \\
\text { Muhammadiyah }\end{array}$ & 0.23 & 0.32 & 0.21 & 0.17 & 0.93 & 4.11 \\
\hline SDIT Al-Mumtaz & 0.11 & 0.16 & 0.21 & 0.17 & 0.65 & 4.02 \\
\hline SDI Mujahidin & 0.11 & 0.08 & 0.10 & 0.13 & 0.43 & 4.07 \\
\hline SDI Al-Azhar & 0.68 & 0.49 & 0.42 & 0.51 & 2.09 & 4.12 \\
\hline & & & & Total & 16.33 \\
\hline & & & & & $\lambda \operatorname{Max}$ & 4.08 \\
\hline \multicolumn{2}{|c|}{$\begin{array}{l}\text { Consistency Index }(\mathrm{CI}) \\
\mathrm{CI}=(\lambda \text { maks }-\mathrm{n}) /(\mathrm{n}-1) \\
\mathrm{CI}=(4.08-4)-(4-1) \\
\mathrm{CI}=0.0273\end{array}$} & \multicolumn{3}{|c|}{$\begin{array}{l}\text { Consistency Rasio (CR) } \\
\mathrm{CR}=\mathrm{CI} / \mathrm{IR} \\
\mathrm{CR}=0.0273 / 0.90 \\
\mathrm{CR}=0.0303 \\
\mathrm{CR}<0.90 \text { Consistent }\end{array}$} & & \\
\hline
\end{tabular}

Tabel 19. Pengukuran Logikal Consistency Alternatif untuk Output dan Pertasi yang Dihasilkan

\begin{tabular}{|c|c|c|c|c|c|c|}
\hline Alternatif & $\begin{array}{c}\text { SDI } \\
\text { Muhammadiyah }\end{array}$ & $\begin{array}{c}\text { SDIT } \\
\text { Al-Mumtaz }\end{array}$ & $\begin{array}{c}\text { SDI } \\
\text { Mujahidin }\end{array}$ & $\begin{array}{c}\text { SDI } \\
\text { Al-Azhar }\end{array}$ & Total & Summary \\
\hline $\begin{array}{l}\text { SDI } \\
\text { Muhammadiyah }\end{array}$ & 0.38 & 0.58 & 0.23 & 0.43 & 1.62 & 4.27 \\
\hline SDIT Al-Mumtaz & 0.19 & 0.29 & 0.35 & 0.43 & 1.25 & 4.29 \\
\hline SDI Mujahidin & 0.19 & 0.10 & 0.12 & 0.07 & 0.47 & 4.11 \\
\hline SDI Al-Azhar & 0.19 & 0.15 & 0.35 & 0.21 & 0.89 & 4.20 \\
\hline & & & & & Total & 16.87 \\
\hline & & & & & $\lambda \operatorname{Max}$ & 4.22 \\
\hline \multicolumn{2}{|c|}{$\begin{array}{l}\text { Consistency Index }(\mathrm{CI}) \\
\mathrm{CI}=(\lambda \text { maks }-\mathrm{n}) /(\mathrm{n}-1) \\
\mathrm{CI}=(4.22-4) /(4-1) \\
\mathrm{CI}=0.0723\end{array}$} & \multicolumn{3}{|c|}{$\begin{array}{l}\text { Consistency Rasio (CR) } \\
\mathrm{CR}=\mathrm{CI} / \mathrm{IR} \\
\mathrm{CR}=0.0723 / 0.90 \\
\mathrm{CR}=0.0803 \\
\mathrm{CR}<0.90 \text { Consistent }\end{array}$} & & \\
\hline
\end{tabular}




\section{KESIMPULAN}

Sistem pendukung keputusan pemilihan sekolah dasar Islam di Pontianak dilakukan dengan menggunakan metode Analytic Hierarchy Process. Terdapat 6 kriteria yang digunakan dalam penelitian ini yaitu akreditasi, proses pembelajaran, kualitas guru, fasilitas sekolah, lingkungan sekolah, serta output dan prestasi yang dihasilkan. Sedangkan alternatif yang dijadikan sampel pada penelitian ini adalah 4 sekolah dasar Islam yang terkemuka di Pontianak yaitu SDI Muhammadiyah 2, SDIT Al-Mumtaz, SDI Mujahidin, SDI Al-Azhar. Berdasarkan hasil perhitungan yang diperoleh dari perhitungan yang dilakukan berdasarkan langkah-langkah pada metode Analytic Hierarchy Process diperoleh bahwa output dan prestasi yang dihasilkan adalah kriteria terpenting dengan nilai 0,488, diikuti dengan kriteria akreditasi 0,359, kemudian kriteria proses pembelajaran 0,253, kriteria kualitas guru 0,158, kriteria fasilitas sekolah 0,150, dan lingkungan sekolah 0,069. Sedangkan hasil penilaian dari alternatif diperoleh nilai yang tertinggi yaitu SDIT Al-Mumtaz dengan total priority value (TPV) 0,502, sedangkan sekolah dengan nilai total priority value (TPV) adalah SDI Mujahidin dengan nilai 0,282. Metode AHP jika dibandingkan dengan metode SAW dan TOPSIS lebih memperhitungkan validitas sampai dengan batas toleransi inkonsistensi berbagai kriteria dan alternatif yang dipilih oleh para pengambil keputusan.

\section{SARAN}

Untuk penelitian selanjutnya dapat menambahkan lebih banyak alternatif dan tidak terbatas hanya dengan jumlah alternatif tertentu dan dapat mengembangkan kriteria menjadi sejumlah sub kriteria dan sub alternatif agar hasil dalam menentukan tingkat prioritas akan menjadi lebih maksimal. Selain itu bisa dibangun sistem yang berbasis web sehingga dapat membantu orang tua yang akan menyekolahkan anaknya di sekolah dasar Islam Pontianak yang tepat sesuai dengan harapan orang tua.

\section{DAFTAR PUSTAKA}

[1] Scoolmap Kota Pontianak, Tabel Sekolah SD/MI dan Jumlah Siswa, (http://schoolmap.dindikptk.net/siswa_rkpjlh.php?jenjang=SD/MI\&tahun=2012, diakses tanggal 3 Nopember 2016.

[2] Alter, 2002, Konsep dan Aplikasi Sistem Pendukung Keputusan, Andi, Yogyakarta.

[3] Faisal, Permana, S. D. H., 2015, Sistem Penunjang Keputusan Pemilihan Sekolah Menengah Kejuruan Teknik Komputer dan Jaringan yang Terfavorit dengan Menggunakan MultiCriteria Decision Making, Jurnal Teknologi Informasi dan Ilmu Komputer, vol 2, no 1, hal 11-19.

[4] Khasanah, F. N., Permanasari, A. E., Kusumawardani, S. S., Fuzzy Multi Attribute Decision Making for Major Selection at Senior High School, ICETEA 2015, Surakarta, 15 Oktober 2015.

[5] Doka, K. M., Ahmad, F., Shamsuddin, S. N. W., Ghazali, N., Awang, W. S. W., 2014, Integrated Decision Support System for Human Resource Selection Using TOPSIS Based Models, The Third International Conference on Informatics \& Applications (ICIA2014), Kuala Trengganu, 8-10 Oktober 2014.

[6] Saaty, T. L., 2008, Decision Making with the Analytic Hierarchy Process, International Journal of Services Sciences, vol 1, no 1, hal 83-98.

[7] Saaty, T. L., 2000, Fundamentals of Decision Making and Priority Theory with The Analytic Hierarchy Process, RWS Publications. 